\title{
THE RESTRUCTURING OF THE SPANISH BANKING SYSTEM: ANALYSIS OF THE EFFICIENCY OF FINANCIAL ENTITIES
}

\begin{abstract}
Purpose - This paper analyses the performance of Spanish banking entities between 2009 and 2013, a period marked by the reform of the banking system with a large number of mergers and integrations.

Design/methodology/approach - Firstly, efficiency is measured applying the Data Envelopment Analysis methodology and, then, the Malmquist index is calculated to assess its evolution.
\end{abstract}

Findings - The results show that most of the entities have improved their performance from the production approach. However, from the intermediation approach, the efficiency of the sample has deteriorated, which raises questions about the sustainability of the traditional banking business when the current credit restriction strategy is long lasting.

Practical implications - The comparative analysis demonstrates that, after the deep reforms carried out in Spain, the banking entities maintain similar efficiency rankings to those they had at the beginning of the period analysed. This shows that the reform has created new groups that operate adequately, avoiding the closing of institutions. Despite the better rationalisation of the available resources, the outlook for Spanish banks remains unclear in the current macroeconomic context, which does not favour the banking business.

Originality/value - The study contributes to the literature on Spanish banking system because it adds new empirical evidence about its restructuring and it applies a DEA model to a sample before and after mergers. The authors discuss theoretical and managerial implications and offers suggestions for future research on this field.

Keywords: Banking entities, Mergers, DEA, Malmquist Index, Financial crisis

Acknowledgements: This study was supported by the Spanish National R + D Plan under the Research Project ECO2015-66240-P and the Regional Government of Aragón and the European Social Fund under the Research Project S05. 


\section{Introduction}

The Spanish financial system underwent an uncontrolled growth during the first decade of the $21^{\text {st }}$ century. During this period, financial entities (especially savings banks) expanded throughout the country, opening new branches even in zones outside their core area and the volume of bank loans rose to unsustainable figures. Most of this money was obtained from overseas wholesale markets to fund the real estate sector. With the global economic crisis, and the burst of the Spanish housing bubble, the savings banks became indebted and had a high percentage of credits on their balance sheet, which generated a greater risk of insolvency. The unnecessary excess of productive capacity, based on the growth of promoters and builders loans, with high default risks, was not well-assessed at the time. Excessive borrowing in wholesale markets, which caused a significant weakening of the core capital of savings banks, and the high default ratio in Spain, led to their balance sheets being flooded with property assets that lost their value daily.

In this paper, we study this transformation process of the Spanish banking sector from the point of view of the efficiency of the entities. Our objectives are, first, to evaluate whether the reforms implemented have led to a better performance of the system and, second, to identify the entities that have shown a better behaviour in this process. To do so, we carry out a comparison of the efficiency of Spanish banking entities in 2009 and 2013, applying the Data Envelopment Analysis (DEA) and the Malmquist index to analyse efficiency changes. Unlike prior studies dealing with bank efficiency, we have measured the performance of financial entities using two different approaches to efficiency, the production and the intermediation approach. Thus, the results are expected to provide a more comprehensive view of the effects of the restructuring of the Spanish banking sector on the entities' performance. The analysis sheds light on the 
effectiveness of the strategy adopted by the Spanish regulator that may be relevant to assist other countries whose banking systems are facing similar situations.

The paper is organised as follows. In the next section, we develop the context of the study. The third section describes the effect of banking mergers on efficiency. The fourth section explains the research methodology and data used in the analysis. The fifth section presents the empirical results. The discussion is contained in the sixth section and, finally, the seventh section draws the conclusions.

\section{Context}

At the end of the decade, so many savings banks were threatened by insolvency that the financial sustainability of the whole system was at risk. In response to this situation, the banking sector embarked upon a recapitalization and restructuring process to regain trust in the system. Among the measures adopted, the following can be highlighted:

- Creation of the Fund of Orderly Bank Restructuring (FROB) to channel public financial support to financial entities (Royal Decree-law 9/2009).

- Reform of the legal regime of savings banks (Royal Decree-law 11/2010) to enhance their capitalization and the professionalization of their governing bodies. Later, the Law 26/2013 on savings banks and banking foundations established that savings banks had to transfer their financial activity to a credit institution and enter into a banking foundation transformation agreement if they had a value of more than 10,000 million euros in total consolidated assets or a market share of more than 35\% in deposits in their Autonomous communities ${ }^{1}$.

- Increase of core capital requirements through Basel III, aimed at strengthening the solvency of financial entities by increasing bank liquidity and decreasing bank leverage.

\footnotetext{
${ }^{1}$ Autonomous communities is the official Spanish name for regions.
} 
As a result, the Spanish financial sector has undergone a conversion process of its commercial banking in which the number of institutions decreased from 54 in 2009 to 17 in 2013 (See Appendix 1). In this process, Spanish savings banks have proven to be the weakest part of the national financial system (Parejo et al., 2011). The vast majority of the 45 savings banks that existed in 2009 have been nationalized or acquired by commercial banks (losing importance in the long term, as in other European countries): only 2 small savings banks and 4 groups remain. Autonomous communities have lost their influence over the savings banks, which the Spanish central government now controls.

Another important factor, in addition to the restructuring of the banking system is the legal form of Spanish savings banks. They were private foundations and could not issue capital. However, entities resulting from the integration process can increase their equity by issuing capital in financial markets. This leads to the improvement of the core capital that, in a banking entity, is made up of nominal capital and reserves and defines its solvency level. A higher core capital indicates that an entity has a higher equity compared to risk-weighted assets. These assets include deposits from central banks (no risk) and industrial interests with a high risk. Savings banks investments in real estate were not risk controlled and supervised. With consolidation, it is expected that entities control their risk exposure by investing less aggressively in non-hedgeable risks. Banks should hedge any risk at fair-market values and hold capital for absorbing risks which cannot be hedged (Froot and Stein, 1998).

\section{Banking mergers and efficiency}

The scope and framework of this study can be explained by the changes that have taken place in the Spanish banking sector in recent years. In this section, we analyse the 
factors that contribute to explaining the effect of mergers on the efficiency of Spanish banking entities.

According to traditional economic theory, mergers and acquisitions (M\&A) create synergies and lowers costs through economies of scale (Williamson, 1968). M\&A among banking entities are very frequent around the world and, currently, the banking sector is using them as a strategy for achieving larger size and being more competitive (Vander Vennet, 2002; Khan, 2011; Alhasan and Asare, 2016). Consolidation will be sustainable in the long run only if it increases efficiency or does not reduce efficiency substantially (Berger et al., 2001). However, more care should be taken in terms of the creation of excessive market power from M\&A. According to Berger and Humphrey (1994), increased market concentration in the United States may lead to slightly less favourable prices of some deposit and loan accounts for consumers as well as a decrease in banking efficiency because bank managers enjoy some of the benefits of market power, such as reduced effort levels. These authors assert that this is not likely to occur in Europe, as these mergers tend to intensify market competition, resulting in more favourable prices for consumers and greater efficiency. In any case, country-specific factors, such as different banking regulations and the different managerial strategies implemented by banking entities to face the new challenges, are important determinants in explaining differences in bank efficiency levels (Casu and Molyneux, 2003).

In the last five years, a wave of consolidation has transformed the Spanish banking industry. The financial crisis has intensified this process and acquisitions have been considered a means to prevent bank failures. The ability to correctly calculate the risk of each institution is crucial for good banking supervision and the stability of the financial system (García-Céspedes and Moreno, 2014). A bigger entity is considered more competitive and less risky than a smaller one. When an entity is less risky, it obtains 
funding in the interbank credit market with better economic conditions. Since the main activity of a bank is based on capturing customer money to lend to other customers, the entity that gets more and cheaper funding in the interbank market will be able to pay a lower interest rate, which will generate a higher margin. Net interest income is the most important item in the income statement of the entity (supplemented by utility commissions and other concepts) and has a direct relationship to efficiency. In line with this, Maudos et al. (2002b) find higher levels of inefficiency in revenues than in costs and analyse the importance of size to explain the inefficiencies in the revenue side of banking. It is important to take into account that the resulting entity will be less risky if it designs a restructuring strategy that includes the reduction of operating expenses such as salaries, central services expenses, number of branches, technology expenses and buildings. Currently, banks are decreasing staff costs and making labour force adjustments to obtain a higher operational efficiency, which generates stress and insecurity for employees of banking entities (Konstantopoulos et al., 2009). Other expenses that have been reduced are the rents of branches, custodial fees, security costs, communications costs, etc.

The growth of Spanish banking entities was achieved by opening branches, which generated high overheads. In the crisis period, branches became non-profitable and have burdened the income statement, the opposite of what was intended. As consequence, it was necessary to close offices and to reduce personnel and other costs. If the entity is large, for instance, merged entities, increasing the number of offices does not lead to improved profitability unless it expands into new geographical areas. In a recession, improved performance is usually achieved by reducing the number of offices. If the entity is oversized, it should reduce its costs, trying to maintain the business achieved in the expansionary phase. If banking entities are able to keep their number of clients 
despite closing branches, gains emerge from savings in staff and rental costs. However, cost reduction does not necessarily imply an improvement in efficiency (TortosaAusina, 2002; Carbo et al., 2003) as the evolution of income also influences this magnitude.

Although the integration process is taking place to obtain long-term synergies and increases performance (Bernad et al., 2013), results about the benefits derived from mergers are not consistent (Gutiérrez Fernández et al., 2013).

\section{Methodology and data}

We have used the Data Envelopment Analysis (DEA) to analyse the factors that determine the performance of banking entities. Our database is made up of observations of 17 entities in 2009 and $2013^{2}$. The DEA technique is a non-parametric method based on linear programming that was developed by Charnes et al. (1978) and Banker et al. (1989). It is used to measure the relative efficiency of various decision-making units (DMU), which are organizations where several inputs and outputs are taken into account. It compares the inputs and the outputs of DMUs by establishing a frontier of efficiency and by evaluating efficiency relative to that frontier. Therefore, a DMU is qualified as efficient if no other DMU can produce more outputs by using an equal or smaller quantity of inputs, or if no other DMU can use fewer inputs to produce an equivalent or higher quantity of outputs. DEA coefficients give an idea of the theoretical maximum quantity of inputs that could be reduced without affecting the output level (for instance, a coefficient $\mathrm{X}$ means that it would be possible to obtain the same output with a saving of $(100-\mathrm{X}) \%$ of inputs). When the coefficient is 1.00 the DMU is comparatively efficient, i.e. the DMU optimizes its resources to obtain the output.

\footnotetext{
${ }^{2}$ For 2009, the study considers the sum of the amounts of the input/output variables of the entities that form the banking groups of 2013.
} 
There are two main alternatives for measuring banking activity, namely, the production approach and the intermediation approach. The first considers banking institutions as producers of services for their customers. The intermediation approach expands the definition of inputs to include deposits and suggests measures of banking output according to the time value of money, basically in earning assets. It considers banking institutions primarily as intermediating entities between savers and investors. Prior studies have measured performance by focusing on one of these two alternatives, particularly the intermediation approach (Illueca et al., 2009), but there is, as far as we know, no research that considers both approaches. In this study, we adopt this dual perspective.

For the production approach, the number of branches and the staff have been included as inputs in the model. As outputs, we include the amount of deposits, loans and negotiable securities. Authors such as Ferrier and Lovell (1990), Grifell-Tatje and Lovell (1996), Fried et al. (2003), Prior (2003), Kumbhakar et al. (2011) and Camanho and Dyson (2005) have followed the production approach or have included these variables in their studies. For the intermediation approach, the inputs are the amount of deposits and interest and charges paid. As outputs, we include loans, interest and fees received and the inverse of impairments. The intermediation approach with these inputs and outputs has been used by Maudos et al. (2002a), Carbo et al. (2003), Cuesta and Zofío (2005), Illueca et al. (2009), Williams et al. (2011) and Pina et al., (2016), among others.

After running the DEA model, we have calculated the Malmquist index for the period 2009 to 2013. The Malmquist index makes use of distance functions to measure productivity change over time, and can be multiplicatively decomposed into an efficiency change index and a technological change index. 
Caves et al. (1982) proposed that the Malmquist index between time periods $t$ and $(t+1)$ can be defined as:

$$
M_{t, t+1}\left(y^{t}, y^{t+1}, x^{t}, x^{t+1}\right)=\left[\frac{D^{t}\left(y^{t+1}, x^{t+1}\right)}{D^{t}\left(y^{t}, x^{t}\right)} \times \frac{D^{t+1}\left(y^{t+1}, x^{t+1}\right)}{D^{t+1}\left(y^{t}, x^{t}\right)}\right]^{1 / 2}
$$

where $\mathrm{D}$ represents the distance function and the value of $\mathrm{M}$ is the Malmquist index. The first ratio measures the productivity change from period $t$ to period $(t+1)$ using period $t$ technology as a benchmark. The second ratio measures the productivity change from period $t$ to period $(t+1)$ using period $(t+1)$ technology as a benchmark. From an input-orientated perspective, a value of $\mathrm{M}$ less than one denotes productivity growth, a value greater than one indicates productivity decline, and $\mathrm{M}$ equal to 1 corresponds to stagnation.

\section{Results of the study}

In this section, the results obtained using the DEA and Malmquist methodology are presented. Table 1 shows the descriptive statistics of the variables included in the analyses. As can be seen, all the indicators, except for the negotiable securities, experienced a significant decline in terms of their mean during 2009-13, evidencing the banking activity downturn in this period. The growth in the volume of negotiable securities is mainly due to the intensive purchase of public debt. Spanish Government bonds held by Spanish banks increased from 165,000 million euros in 2011 to 300,000 million euros in 2013 (Deutsche Bundesbank, 2013). The other positive figure is the $42 \%$ reduction over the period of the impairments of financial assets. The statistical magnitudes (std dev, max and min) reflect the great heterogeneity of the Spanish banking system, particularly the differences between the biggest and smallest entities. 
Table 2 presents the results of the production approach.

[Insert Table 2 about here]

As can be seen, the results of the constant returns to scale (CRS) model in 2009 show that Banco Santander, Bankia and Bankinter constitute the efficient frontier. So, neither the size nor the nature of banking entities are per se factors that explain differences in efficiency because the efficient DMUs are a big bank (Banco Santander), a savings bank (Bankia) and a small bank (Bankinter). However, the three least efficient DMUs -below $60 \%$ - are the smallest entities in the sample. All the other entities obtain efficiency scores between $70 \%$ and $86 \%$. The analysis of efficiency with the variable returns to scale (VRS) model shows similar results to the CRS model and, as a consequence, the scale efficiency (CRS/VRS) is close to $100 \%$ for most entities, which indicates that they are operating on an appropriate scale and that size is not the cause of their inefficiencies, with the exceptions of Caja Pollença and Caja Ontinyent. Both these entities, the two remaining saving banks in the sample, show a low efficiency scale, which suggests that the size of these entities is smaller than the optimum.

Bankinter and Bankia are the only entities that obtain the maximum efficiency score in 2013. Although, by this year, all the banks had reduced both the number of branches and the number of employees, Bankinter has significantly increased the amount of its deposits and loans while the efficiency of Bankia is based on the variable negotiable securities, the amount of which increased by 64\% during 2009-13, proportionately higher than the rest. It should be highlighted that the increase of the resources of Bankia after the merger was mainly due to the public financial assistance it received. Bankia was recapitalised in 2012 with more than €20bn of public money from the FROB. In the other entities, the decrease of branches and staff was accompanied by lower deposits and loans, except for Banco Popular, Banca March and Banco Sabadell whose deposits 
increase. As a consequence, there is a wider gap in 2013 than in 2009 between the efficiency of Bankinter and Bankia and the rest, which have scores of lower than $85 \%$. In contrast to 2009, the VRS model for 2013 shows significant differences in Banco Santander, BBVA, La Caixa, Bankia and Caja Pollença, which obtain a score of 100\%, while others obtain similar scores to the CRS model. As a consequence, the evaluation of the scale efficiency allows us to identify a group of entities made up of Banco Santander, BBVA, La Caixa, Popular, Sabadell, Caja Pollença and Caja Ontinyent whose inefficiency can be explained by their size. For the other entities, inefficiency is due to other causes. Scale inefficiencies arise for 5 of the 6 biggest Spanish financial entities and for the 2 smallest.

Finally, the Malmquist index, which shows the evolution of the efficiency, reveals that all entities have improved their productive efficiency in the period analysed, especially Banca March, Caja3 and Caja Pollença. During this period, financial entities drastically reduced the number of branches and staff to save costs and compensate for the prolonged contraction of their commercial activity.

Table 3 presents the results of the intermediation approach.

[Insert Table 3 about here]

The analysis of efficiency with the CRS model shows that Banco Santander, Bankia, Banco Sabadell, Bankinter and Caja Pollença are the most efficient entities in 2009. Once again, the results indicate that the size and the nature of entities are not factors that explain inefficiency. In this model, the maximum score obtained by one of the smallest entities, Caja Pollença, indicates that a company can be small and efficient when it manages its resources adequately. Unicaja and Caja3 obtain the lowest scores (around $65 \%)$, which indicates that these entities are not able to profitably transform deposits into loans. The VRS model confirms the results from the CRS model, except that 
BBVA now obtains a score of $100 \%$. Similar to the production approach, the scale efficiency is close to $100 \%$ for most of the entities. So, the size of each entity is appropriate to acting as intermediaries in this sector.

Banco Popular, Banco Sabadell, Caja Pollença and Caja Ontinyent are the efficient DMUs in 2013. Among the less efficient entities, Banco Santander, BBVA, La Caixa and Bankia obtain a score of around $60 \%$, which is $30 \%$ less than the efficiency they obtained in 2009. These results show that the bigger Spanish banks have not run their businesses efficiently or fulfilled their function as intermediaries. The scale efficiency is especially low for Banco Santander, BBVA and La Caixa. This indicates that these entities do not operate with an optimum scale and their size may be encumbering their efficiency.

The Malmquist index for the intermediation approach presents higher scores than for the production approach. This indicates that the efficiency of the sample in the period 2009-2013 has deteriorated considerably and that the traditional banking business (granting credit and capturing deposits) has been run inefficiently.

\section{Discussion}

This paper studies the effect of bank consolidation on the efficiency of Spanish banking entities. To analyse how the process of mergers in Spain has influenced efficiency, we have run two DEA models (production and intermediation approaches) for 2009 and 2013 and calculated the Malmquist index for both approaches. Our findings indicate that the efficiency of banks from the production approach improved in the period 20092013, the period in which the mergers took place, but it did not improve from the intermediation approach. These results show that the performance of the financial entities is a multifaceted concept and, as a consequence, its measurement must be addressed from different approaches. Although there is a vast literature analysing the 
efficiency of financial institutions, most studies focus on just one of these dimensions, giving only a partial view of their performance. The experience of the Spanish banking system reveals that production and intermediation are different and independent aspects of the activity of financial entities. The analysis of the restructuring of the Spanish banking system that began after its collapse in 2009 leads to different conclusions depending on the perspective adopted.

From the point of view of the services production activity of entities (production efficiency), the reforms undertaken have contributed to improving the efficiency of the system, encouraging a more rational allocation of inputs and outputs. The extraordinary expansion of most of the financial entities in the years prior to the crisis led to an excess of capacity in the Spanish banking industry (Carbó and Rodríguez, 2016). Thus, the restructuring of the Spanish financial system was necessary to rebalance the supply and demand of financial entities. As we know, mergers and acquisitions in the Spanish banking industry during the 90s, when the number of banks and saving banks fell from around 80 to 51, did not lead to significant improvements in their efficiency (Fuentes and Sastre, 1999). This is coherent with the hypothesis of Palomo and Sanchis (2010) who argue that mergers are more successful when they are underpinned by reasons of economic rationality and not when they respond to the growth and expansion of the financial entities, as was the case in the 90s. The consolidation process initiated in 2009 has increased the concentration of the banking industry, enabling financial entities to reduce the number of employees and branches by concentrating part of their operational activity in central departments. At the same time, the public aid of around 60,000 million euros that was injected into the banks and the purchase of part of their toxic assets and non-performing loans by the Spanish "bad bank” (SAREB), created in 2012, have contributed to cleaning up the banks' balance sheets and to underpinning the 
banking business. Furthermore, the reforms in the Spanish banking system seem to have been well-planned because, with few exceptions, the entities maintain similar rankings.

From the point of view of the intermediation activity (intermediation efficiency), the results show a decline in the productivity of all financial entities during the period analysed. This means that the efficiency of the sample has fallen and that the traditional banking business (granting credit and capturing deposits) has been run inefficiently. So, the measures implemented in the Spanish banking system have proven to be ineffective or, at least, not sufficient to revitalise the financial system and to make the entities profitable again. As a consequence, uncertainty persists about the survival of some banks and it seems clear that new reforms will be needed. There are some factors which may help explain the increasing pressure on the banking industry and the consequent delay of a return to profits for many financial institutions at European level and, particularly, in Spain. First, the current prolonged period of low interest rates has a negative impact on the profitability of banks because it diminishes their margins and banks have to take higher risks to increase profits (Bachiller et al., 2016). The negative impact of this current low interest rate environment is more severe in banking systems that, like the Spanish, have a high degree of reliance on the traditional banking model. For the smallest banks in Spain, it is even more difficult to compensate for these lower margins with other activities (Ocaña and Faibiscenko, 2016). Nevertheless, the results of this study do not corroborate this perspective because four of the biggest banks show the worst performance evolution. Second, the stricter financial regulation imposed by the central banks with the aim of increasing the transparency and solvency of banks may be having a negative impact on their capacity to augment credit flows and productive investments. Moreover, as the European economy is still weak, banks are more cautious when analysing risks. This indicates that the improvement in solvency has been to the 
detriment of profitability. Finally, the drastic deterioration of the Spanish economy during the period analysed, with an unemployment rate rising from $13.8 \%$ in 2008 to $25.7 \%$ in 2013, brought about an ongoing fall in domestic demand. As a consequence, the rate of non-performing loans grew from $4.97 \%$ in 2009 to $13.77 \%$ in 2013 and bank lending fell into a vicious circle of less funding, less demand and greater arrears.

The analysis shows that neither the size nor the nature of the banking entities are per se factors that explain differences in efficiency because the efficient DMUs include a big bank (Banco Santander), a savings bank (Bankia) and a small bank (Bankinter). So, a company can be small and efficient if it manages its resources adequately, that is, if it is able to profitably transform deposits into loans.

\section{Conclusions}

The efficiency of banking entities has multiple dimensions and not all of them are necessarily correlated. Therefore, studies that analyse efficiency must limit the scope of their conclusions to the dimensions addressed.

The comparative analysis undertaken demonstrates that, despite the deep reforms carried out in Spain, the efficiency of the banking sector maintains a similar ranking to that which it had at the beginning of the period analysed only from the point of view of the production approach. This shows that the reforms have acted proportionately through the banking system, avoiding the closing of institutions. Furthermore, entities that do not operate on an optimum scale can be profitable, for instance, when they offer specialized treatment for specific niche markets. So, the future performance of Spanish banking groups will depend on their capacity to promote a profitable business and select the best investment opportunities. 
The consolidation of the Spanish banking sector has contributed to improving the productive efficiency of entities by rationalising the available resources. Mergers have been carried out to save costs and not to increase market share or eliminate competitors' power. However, at the same time, the strong contraction in the main activity of the financial institutions, granting credits, has led to a decrease in efficiency from the point of view of intermediation. The current macroeconomic context, in particular the low interest rates and high default rates, has affected the profitability of the banking business. This will have to be corrected to maintain the sustainability of some entities and, in the case of Bankia, to pay back the financial aids given by Europe. Meanwhile, new mergers of banks cannot be ruled out.

This study identifies some interesting implications for policymakers; because, when considering the process of banking mergers to strengthen this sector, economic issues other than growth and expansion criteria should be taken into account. Some questions that arise for future research are the influence of the regulation on the performance of banking entities and the analysis of the banking sector after transnational mergers. The consolidation of this sector is still at an intermediate stage. 


\section{References}

Alhassan, A. L., \& Asare, N. (2016). "Intellectual capital and bank productivity in emerging markets: evidence from Ghana”. Management Decision, Vol. 54 No. 3, pp. 589-609.

Bachiller, P. Martín, E. and Bachiller, A. 2016. “Consecuencias de la restructuración del sistema bancario español: un análisis empírico de la evolución de la eficiencia”. Revista de Contabilidad y Tributación, Vol. 397, pp. 161-182.

Banker, R. D. Charnes, A. Cooper, W. Swarts, J. and Thomas, D. 1989. "An introduction to data envelopment analysis with some of its models and their uses." Research in Governmental and Non-profit Accounting, Vol. 5, pp. 125-163.

Berger, A. N. DeYoung, R. Genay, H. and Udell, G. F. 2000. Globalization of financial institutions: Evidence from cross-border banking performance. Brookings-Wharton Papers on Financial Services: 2000.

Berger, A.N. Humphrey, D.B. 1994. Bank scale economies, mergers, concentration and efficiency: the US experience. Wharton School Centre for Financial Institutions, Working Paper 94-25, University of Pennsylvania.

Bernad, C. Fuentelsaz, L. and Gomez, J. 2013. "The consequences of mergers on the profitability of Spanish savings banks.” The Service Industries Journal, Vol. 33 No. 2, pp. 266-278.

Camanho, A. S., \& Dyson, R. G. (2005). "Cost efficiency measurement with price uncertainty: a DEA application to bank branch assessments”. European Journal of Operational Research, vol. 161 No. 2, pp. 432-446.

Carbo, S. Gardener, E.P.M. and Williams, J. 2003. "A note on technical change in banking: the case of European savings banks.” Applied Economics, Vol. 35 No. 6, pp. 705-719.

Carbo, S. and Rodríguez, F. 2016. "The Spanish financial system in the new political era.” Spanish economic and financial outlook, Vol. 5 No. 2, pp. 19-33.

Casu, B. and Molyneux, P. 2003. “A comparative study of efficiency in European banking.” Applied Economics, Vol. 35 No. 17, pp. 1865-1876.

Caves D.W. L. R. Christensen and W. E. Diewert. 1982. "The Economic Theory of Index Numbers and Measurement of Input, Output and Productivity.” Econometrica, Vol. 50, pp. 1393-414.

Charnes, A. W.W. Cooper, and E. Rhodes. 1978. "Measuring Efficiency of DecisionMaking Units.” European Journal of Operational Research, Vol. 2 No. 6, pp. 42944. 
Cuesta, R. A. and Zofío, J. L. 2005. "Hyperbolic efficiency and parametric distance functions: with application to Spanish savings banks." Journal of Productivity Analysis, Vol. 24 No. 1, pp. 31-48.

Deutsche Bundesbank. 2013. "Monetary policy and banking business" in Deutsche Bundesbank monthly report. November 2013, Vol 65 (11) pp 23-31. https://www.bundesbank.de/Redaktion/EN/Downloads/Publications/Monthly_Repo rt/2013/2013_11_monthly_report.pdf?_blob=publicationFile

Ferrier, G and Lovell, CAK. 1990. "Measuring cost efficiency in banking: econometric and linear programming evidence”. Journal of Econometrics, Vol. 46, pp. 229-245.

Fried, H. O., Lovell, C. K., and Eeckaut, P. V. (1993). Evaluating the performance of US credit unions. Journal of Banking \& Finance, Vol. 17, No. 2, pp. 251-265.

Froot, K. A. and Stein, J. C. 1998. "Risk management, capital budgeting, and capital structure policy for financial institutions: an integrated approach.” Journal of Financial Economics, Vol. 47 No. 1, pp. 55-82.

Fuentes, I and Sastre, T. 1999. "Mergers and acquisitions in the Spanish banking industry: some empirical evidence”. Banco de España. Servicio de Estudios. Documento de Trabajo 9924

García-Céspedes, R. and Moreno, M. 2014. "Estimating the distribution of total default losses on the Spanish financial system." Journal of Banking and Finance, Vol. 49, pp. 242-261.

Grifell-Tatje, E., \& Lovell, C. K. (1996). Deregulation and productivity decline: The case of Spanish savings banks. European Economic Review, Vol. 40 No. 6, pp. 1281-1303.

Gutiérrez, M. Palomo, R. J. and Fernández G. 2013. "Spanish savings banks: A claimed reordering under criteria of economic and social rationality?." Cuadernos de Economía y Dirección de la Empresa, Vol. 16, pp. 250-258.

Illueca, M. Pastor, J.M. and Tortosa-Ausina, E. 2009 "The effects of geographic expansion on the productivity of Spanish savings banks.” Journal of Productivity Analysis, Vol. 32 No. 2, pp. 119-143.

Kickert, W. 2012. "State Responses to the Fiscal Crisis in Britain, Germany and the Netherlands.” Public Management Review, Vol. 14 No. 3, pp. 299-309.

Khan, A.A. 2011 Merger and Acquisitions (MandAs) in the Indian Banking Sector in Post Liberalization Regime. International Journal of Contemporary Business Studies, Vol. 2 No. 11, pp. 31-45. 
Konstantopoulos, N., Sakas, D., \& Triantafyllopoulos, Y. (2009). "Lessons from a case study for Greek banking M\&A negotiations”. Management Decision, Vol. 47 No. 8, pp. 1300-1312.

Kumbhakar, S.C., A. Lozano-Vivas, C.A.K. Lovell, and I. Hasan. (2001). “The Effects of Deregulation on the Performance of Financial Institutions: The Case of Spanish Savings Banks”. Journal of Money Credit and Banking, 33(1), 101-120.

Maudos, J. Pastor, J. M. Perez, F. and Quesada, J. 2002b. “Cost and profit efficiency in European banks.” Journal of International Financial Markets, Institutions and Money, Vol. 12 No. 1, pp. 33-58.

Maudos, J. Pastor, J.M. and Perez, F. 2002a "Competition and efficiency in the Spanish banking sector: the importance of specialization.” Applied Financial Economics, Vol. 12 No. 7, pp. 505-516.

Ocaña, C. and Faibishenko, A. 2016. "Challenges ahead for the banking industry." Spanish economic and financial outlook, Vol. 5 No. 2, pp. 53-65.

Palomo, R. and Sanchís, J. 2010. "Efectos de las fusiones sobre la concentración y la eficiencia bancaria: el caso de las Cajas Rurales y los retos de la crisis financiera.” Spanish Journal of Finance and Accounting, Vol. 39, pp. 289-319,

Parejo, J.A. García, A.C. and Gámir, J.A.P. 2011. Manual de sistema financiero español, Ariel.

Pina, V. Torres, L. and Bachiller, P. (2016). "Political Influence and the Performance of Nonprofit Spanish Banks”. Nonprofit Management and Leadership, Vol. 46 No. 4, pp. 471-488.

Tortosa-Ausina, E. 2002 "Bank cost efficiency and output specification.” Journal of Productivity Analysis, Vol. 18, pp. 199-222.

Vander Vennet, R. 2002. "Cost and profit efficiency of financial conglomerates and universal banks in Europe.” Journal of Money, Credit, and Banking, Vol. 34 No. 1, pp. 254-282.

Williams, J. Peypoch, N. and Barros, C. P. 2011. "The Luenberger indicator and productivity growth: a note on the European savings banks sector." Applied Economics, Vol. 43 No. 6, pp. 747-755.

Williamson, O. E. 1968. "Economies as an antitrust defense: The welfare tradeoffs." The American Economic Review, Vol. 85 No. 1, pp. 18-36. 
Table 1: Input and output variation of the Spanish financial entities in the period 2009-2013

\begin{tabular}{|c|c|c|c|c|c|c|c|c|c|}
\hline & \multicolumn{4}{|c|}{2009} & \multicolumn{4}{|c|}{2013} & \multirow{2}{*}{$\begin{array}{c}\% \% \\
\text { VARIATION } \\
2009-13 \\
\end{array}$} \\
\hline & Mean & $\max$ & $\min$ & std dev & Mean & $\max$ & min & std dev & \\
\hline Branches & 2,220 & 8,597 & 21 & 2,302 & 1,413 & 5,647 & 20 & 1,576 & $-36 \%$ \\
\hline Staff & 12,909 & 39,557 & 87 & 12,617 & 9,059 & 30,437 & 80 & 9,96 & $-30 \%$ \\
\hline $\begin{array}{l}\text { Deposits } \\
\text { (thousands } € \text { ) }\end{array}$ & $77,758,455$ & $240,156,183$ & 289,16 & $79,050,045$ & $67,565,156$ & 207,374,182 & 380,8 & $69,375,894$ & $-18 \%$ \\
\hline $\begin{array}{l}\text { Loans } \\
\text { (thousands } € \text { ) }\end{array}$ & $93,849,407$ & $303,241,679$ & 274,87 & $99,680,666$ & $64,636,930$ & $215,120,571$ & 291,91 & $73,379,320$ & $-31 \%$ \\
\hline $\begin{array}{l}\text { Securities } \\
\text { (thousands } € \text { ) }\end{array}$ & $29,254,240$ & $125,585,781$ & 42,062 & $39,540,268$ & $34,273,227$ & $137,470,951$ & 55,131 & $44,191,448$ & $17 \%$ \\
\hline $\begin{array}{l}\text { Interest paid } \\
\text { (thousands } € \text { ) }\end{array}$ & $2,968,900$ & $9,757,704$ & 9,126 & $3,200,658$ & $1,791,765$ & $7,614,325$ & 7,732 & $2,281,591$ & $-40 \%$ \\
\hline $\begin{array}{l}\text { Interest } \\
\text { income } \\
\text { (thousands } € \text { ) }\end{array}$ & $5,749,300$ & $18,185,211$ & 19,803 & $6,269,711$ & $3,712,605$ & $12,506,649$ & 19,615 & $4,065,603$ & $-35 \%$ \\
\hline $\begin{array}{l}\text { Impairment of } \\
\text { financial } \\
\text { assets } \\
\text { (thousands } € \text { ) }\end{array}$ & $1,850,705$ & $11,582,068$ & 1,704 & $2,907,325$ & $1,064,718$ & $4,196,919$ & 2,125 & $12,683,303$ & $-42 \%$ \\
\hline
\end{tabular}

Source: Author's elaboration from Spanish banking association annual reports 
Table 2: Coefficients of technical efficiency and Malmquist Index (Production approach)

\begin{tabular}{|c|c|c|c|c|c|c|c|c|c|}
\hline & \multicolumn{3}{|c|}{2009} & \multicolumn{3}{|c|}{2013} & \multicolumn{3}{|c|}{ Malmquist Index } \\
\hline & CRS & VRS & CRS/VRS & CRS & VRS & CRS/VRS & $\begin{array}{l}\text { Technical } \\
\text { change }\end{array}$ & $\begin{array}{l}\text { Technologic } \\
\text { al change }\end{array}$ & Malmquist \\
\hline Banco Santander & $100.00 \%$ & $100.00 \%$ & $100.00 \%$ & $85,31 \%$ & $100,00 \%$ & $85,31 \%$ & 1,172 & 0,821 & 0,963 \\
\hline BBVA & $86,47 \%$ & $100,00 \%$ & $86,47 \%$ & $69,71 \%$ & $100,00 \%$ & $69,71 \%$ & 1,240 & 0,708 & 0,878 \\
\hline La Caixa & $73,20 \%$ & $73,20 \%$ & $100,00 \%$ & $58,90 \%$ & $100,00 \%$ & $58,90 \%$ & 1,243 & 0,706 & 0,878 \\
\hline Bankia & $100,00 \%$ & $100,00 \%$ & $100,00 \%$ & $100,00 \%$ & $100,00 \%$ & $100,00 \%$ & 1,000 & 0,862 & 0,862 \\
\hline Banco Popular & $70,85 \%$ & $70,95 \%$ & $99,86 \%$ & $60,69 \%$ & $87,71 \%$ & $69,19 \%$ & 1,167 & 0,689 & 0,804 \\
\hline Banco Sabadell & $76,38 \%$ & $84,07 \%$ & $90,85 \%$ & $53,17 \%$ & $79,07 \%$ & $67,24 \%$ & 1,437 & 0,683 & 0,980 \\
\hline Banca March & $54,98 \%$ & $58,32 \%$ & $94,27 \%$ & $61,20 \%$ & $64,18 \%$ & $95,36 \%$ & 0,898 & 0,682 & 0,613 \\
\hline Bankinter & $100,00 \%$ & $100,00 \%$ & $100,00 \%$ & $100,00 \%$ & $100,00 \%$ & $100,00 \%$ & 1,000 & 0,967 & 0,967 \\
\hline Unicaja & $72,12 \%$ & $72,52 \%$ & $99,45 \%$ & $58,41 \%$ & $58,68 \%$ & $99,54 \%$ & 1,235 & 0,664 & 0,820 \\
\hline Kutxa & $82,83 \%$ & $83,63 \%$ & $99,04 \%$ & $69,46 \%$ & $69,51 \%$ & $99,93 \%$ & 1,192 & 0,678 & 0,809 \\
\hline Ibercaja & $77,20 \%$ & $78,05 \%$ & $98,91 \%$ & $69,87 \%$ & $70,56 \%$ & $99,02 \%$ & 1,105 & 0,696 & 0,769 \\
\hline Caja 3 & $73,74 \%$ & $75,27 \%$ & $97,97 \%$ & $77,67 \%$ & $79,62 \%$ & $97,55 \%$ & 0,949 & 0,718 & 0,682 \\
\hline Liberbank & $80,40 \%$ & $80,96 \%$ & $99,31 \%$ & $56,25 \%$ & $56,31 \%$ & $99,89 \%$ & 1,429 & 0,664 & 0,949 \\
\hline Banco Mare Nostrum & $78,36 \%$ & $78,78 \%$ & $99,47 \%$ & $65,37 \%$ & $65,56 \%$ & $99,71 \%$ & 1,199 & 0,680 & 0,815 \\
\hline Nova Caixa Galicia & $80,08 \%$ & $80,55 \%$ & $99,42 \%$ & $73,69 \%$ & $74,25 \%$ & $99,25 \%$ & 1,087 & 0,711 & 0,772 \\
\hline Caja de Ahorros de Pollença & $44,14 \%$ & $100,00 \%$ & $44,14 \%$ & $39,97 \%$ & $100,00 \%$ & $39,97 \%$ & 1,104 & 0,664 & 0,733 \\
\hline Caja de Ahorros y M. P. de Ontinyent & $46,98 \%$ & $68,37 \%$ & $68,71 \%$ & $36,75 \%$ & $63,21 \%$ & $58,14 \%$ & 1,278 & 0,696 & 0,890 \\
\hline
\end{tabular}


Banking sector consolidation in Spain

\begin{tabular}{|c|c|}
\hline$\underline{2009}$ & $\underline{2013}$ \\
\hline $\begin{array}{l}\text { Banesto } \\
\text { Banco Santander }\end{array}$ & SANTANDER \\
\hline $\begin{array}{l}\text { Caixa d'Estalvis de Catalunya } \\
\text { Caixa d'Estalvis Comarcal de Manlleu } \\
\text { Caixa d'Estalvis de Tarragona } \\
\text { Caixa d'Estalvis de Terrassa } \\
\text { Caixa d'Estalvis de Manresa } \\
\text { Caixa d'Estalvis de Sabadell } \\
\text { BBVA }\end{array}$ & BBVA \\
\hline $\begin{array}{l}\text { Caixa d'Estalvis i Pensions de Barcelona. } \\
\text { Caja de Ahorros Municipal de Burgos } \\
\text { Caixa d'Estalvis de Girona } \\
\text { Caja de Ahorro Provincial de Guadalajara } \\
\text { Caja de Ahorros y Monte de Piedad de Navarra } \\
\text { Caja General de Ahorros de Canarias } \\
\text { Caja de Ahorros Provincial San Fernando de Sevilla y Jerez } \\
\text { Banco de Valencia }\end{array}$ & LA CAIXA \\
\hline $\begin{array}{l}\text { Caja de Ahorros y M. P. de Ávila } \\
\text { Caja de Ahorros de la Rioja } \\
\text { Caja de Ahorros y M. P. de Madrid } \\
\text { Caixa d'Estalvis Laietana } \\
\text { Caja Insular de Ahorros de Canarias } \\
\text { Caja de Ahorros y M. P. de Segovia } \\
\text { Bancaja }\end{array}$ & BANKIA \\
\hline $\begin{array}{l}\text { Banco Popular } \\
\text { Banco Pastor }\end{array}$ & BANCO POPULAR \\
\hline
\end{tabular}




\begin{tabular}{|c|c|}
\hline $\begin{array}{l}\text { Caja Mediterráneo } \\
\text { Caja de Ahorros y M. P. de Gipuzkoa y San Sebastían } \\
\text { Banco Sabadell }\end{array}$ & SABADELL \\
\hline Banca March & BANCA MARCH \\
\hline Bankinter & BANKINTER \\
\hline $\begin{array}{l}\text { Caja Provincial de Ahorros de Jaén } \\
\text { Caja España de Inversiones, Caja de Ahorros y M. P. } \\
\text { UNICAJA } \\
\text { Caja de Ahorros de Salamanca y Soria - Caja Duero }\end{array}$ & UNICAJA \\
\hline $\begin{array}{l}\text { Bilbao Bizkaia Kutxa } \\
\text { Cajasur } \\
\text { Caja de Ahorros de Vitoria y Álava }\end{array}$ & KUTXA \\
\hline Ibercaja & IBERCAJA \\
\hline $\begin{array}{l}\text { Caja de Ahorros de la Inmaculada de Aragón } \\
\text { Monte de Piedad y Caja General de A. de Badajoz } \\
\text { Caja de A. y M. P. del Círculo Católico de Obreros de } \\
\text { Burgos }\end{array}$ & CAJA 3 \\
\hline $\begin{array}{l}\text { Caja de Ahorros y M. P. de Extremadura } \\
\text { Caja de Ahorros de Castilla la Mancha } \\
\text { Caja de Ahorros de Asturias } \\
\text { Caja de Ahorros de Santander y Cantabria }\end{array}$ & LIBERBANK \\
\hline $\begin{array}{l}\text { Caja General de Ahorros de Granada } \\
\text { Caja de Ahorros de Murcia } \\
\text { Caja de Ahorros y M. P. de las Baleares } \\
\text { Caixa d’Estalvis del Penedés }\end{array}$ & MARE NOSTRUM (BMN) \\
\hline $\begin{array}{l}\text { Caja de Ahorros de Galicia } \\
\text { Caixa de Aforros de Vigo, Ourense y Pontevedra }\end{array}$ & NOVA CAIXA GALICIA \\
\hline Caja de Ahorros de Pollença & $\begin{array}{l}\text { Caja de Ahorros de } \\
\text { POLLENÇA }\end{array}$ \\
\hline Caja Ontinyent & Caja ONTINYENT \\
\hline
\end{tabular}

